Article

\title{
Impact of Tree Growth Rate on the Mechanical Properties of Douglas Fir Lumber in Belgium
}

\author{
Jean-Marc Henin ${ }^{1}$, , Caroline Pollet ${ }^{2}$, Benoit Jourez ${ }^{1}$ and Jacques Hébert ${ }^{2}$ \\ 1 Laboratory of Wood Technology, Public Service of Wallonia, Avenue Maréchal Juin 23, \\ 5030 Gembloux, Belgium; benoit.jourez@spw.wallonie.be \\ 2 TERRA Teaching and Research Center, Gembloux Agro-Bio Tech, University of Liège, Passage des Déportés \\ 2, 5030 Gembloux, Belgium; caroline.pollet@guest.uliege.be (C.P.); jhebert@uliege.be (J.H.) \\ * Correspondence: jeanmarc.henin@spw.wallonie.be; Tel.: +32-81-626-440
}

Received: 20 April 2018; Accepted: 6 June 2018; Published: 9 June 2018

check for updates

\begin{abstract}
In the context of questioning the relevance of making Douglas-fir (Pseudotsuga menziesii (Mirb.) Franco) silviculture more dynamic in Wallonia, we evaluated the influence of growth rate on the potential of Douglas-fir lumber for structural uses. Therefore, six trees 120 to $180 \mathrm{~cm}$ in circumference at $1.5 \mathrm{~m}$ were felled in 11 stands whose age varied from 40 to 69 years (mean circumference of the trees $\approx 150 \mathrm{~cm}$; initial planting density from $\approx 2200$ to 4400 seedlings $/ \mathrm{ha}$ ). In total, 706 boards $\left(38 \times 100 \mathrm{~mm}^{2}\right.$ and $70 \times 180 \mathrm{~mm}^{2}$ in cross section) were cut from these trees, whose average ring width ranged between 3 and $7 \mathrm{~mm}$. The density of the wood $(\rho)$ always appeared compatible with the mechanical class C30, regardless of the growth rate of the trees from which the lumber originated. The modulus of elasticity $(\mathrm{E})$ and the modulus of rupture $\left(f_{m}\right)$ displayed by the $38 \times 100 \mathrm{~mm}^{2}$ boards cut from corewood were respectively $30 \%$ and $41 \%$ lower than those observed in outerwood. The latter did not seem affected by growth rate: $\mathrm{E}$ and $f_{m}$ characteristic values remained compatible with structural use, regardless of the mean ring width. Growth rate considerably affects the characteristic values of these mechanical properties when boards are made from corewood. Juvenile growth should therefore be limited.
\end{abstract}

Keywords: Pseudotsuga menziesii (Mirb.) Franco; strength grading; ring width; silviculture; corewood; outerwood

\section{Introduction}

Within the forest landscape of Wallonia (Southern Belgium), Douglas fir (Pseudotsuga menziesii (Mirb.) Franco) has experienced a notable progression in recent decades [1]. Introduced to Belgium during the second half of the 19th century, it is currently one of the main reforestation species in Wallonia: the area covered with Douglas fir in Wallonia in the early 2000s (i.e., slightly more than 20,000 ha) had increased tenfold compared to its 1960 levels [2]. This increase is the consequence of the advantageous properties of its wood [3,4], which are associated with a growth potential significantly higher than that of other resinous species [5-7], as well as with significant ecological plasticity. The latter makes it relatively well adapted to the soil and climatic conditions of Wallonia [8]. The above figures underlie the limited experience of Walloon foresters regarding the silvicultural management of Douglas fir. In these circumstances, the silviculture of this species in Wallonia has so far been substantially inspired by that applied to Norway spruce (in terms of spacing at planting, intensity, timing of thinning, etc.). As reported hereafter, initial planting densities of more than 3000 or even 4000 seedlings/ha have been adopted in the past. Present planting guidelines are 2000-2500 seedlings/ha [7], which is approximately double the densities in the leading production countries of France [9] and Germany [10]. This situation has probably implied an under-exploitation of the production potential of the North 
American species, as shown by data from the Walloon Permanent Forest Inventory (WPFI) according to which the mean annual circumference increment (MACI) in Walloon Douglas fir stands is about $3.2 \mathrm{~cm}$ /year (Lecomte, 2010, pers. com.), while with ad hoc silvicultural management, periodic increments of up to $4 \mathrm{~cm} /$ year can easily be achieved, at least in young stands [11]. As recent research in Germany $[12,13]$ or in the United Kingdom [14,15] has shown, European forest managers are therefore questioning the impact of silviculture on the characteristics of the Douglas fir resource. In France, research on this issue has been carried out longer ago [16-18]. Moved by the same questions, the Public Service of Wallonia has therefore subsidized a vast study in order to assess to what extent it would be opportune to boost Douglas fir silviculture in Wallonia while ensuring the production of a material that offers the widest potential of uses. Hence, the influence of growth rate was evaluated on certain morphological characteristics (bark thickness, taper, branchiness, etc.), on the natural durability of the wood [19], on the physico-mechanical properties of clear wood specimens [20], as well as on the mechanical and visual characteristics of lumber destined for structural applications or cladding [21,22]. In addition to the intrinsic mechanical properties of clear wood, it is also important to ensure that the final product does not suffer excessively from an increase in the growth rate of the trees. Indeed, lumber presents features (knots, resin pockets, etc.) which, despite the valuable properties of the material per se, can prove to be prohibitive in a particular context of use. Moreover, although it is known that a higher growth rate determines lower mechanical properties of Douglas fir wood [12-14,17,20], this trend is less pronounced than in other softwood species [17].

Additionally, given the differences in mechanical properties of core- and outerwood (As defined in [23]) $[13,15,20,24]$, the type of wood should also be taken into account as much as possible in the analysis of the impact of tree growth rate. In this respect, it is important to note that the age at which wood exhibits its maturity characteristics notably relies on the property considered [14]: for example, microfibril angle, tracheid length, or density do not necessarily stabilize from the same growth ring [25]. Moreover, even considering only one property (e.g., specific gravity), the age of transition can vary significantly between trees and provenances [26], this age being under "appreciable genetic control" [27]. It should also be noted that a slightly earlier transition to maturity in slower-growing trees has been reported [14]. However, if significant at $1.3 \mathrm{~m}$, this impact is no longer significant at $8 \mathrm{~m}$ height. In fact, if outerwood is characterized by relatively stable properties, those of corewood evolve from the pith to the levels specific to outerwood: the transition between core- and outerwood is therefore gradual. According to [15,28], who respectively studied British and German Douglas fir, the mature character of wood is generally observed at an age between 10 and 20 years (although full maturity can only be observed beyond the 30th growth ring).

Finally, the Construction Products Regulation CPR 305/2011 has for some years imposed upon European sawmillers the grading of lumber intended for structural applications, which in Western Europe remains the main outlets of Douglas fir.

In this context, the research presented here aims at evaluating, from the perspective of lumber grading, to what extent growth rate (assumed to be representative of silviculture) influences the potential use of Douglas fir boards for structural applications.

\section{Materials and Methods}

\subsection{Material}

The experimental material was collected from 11 even-aged stands where the average Douglas fir circumference was about $150 \mathrm{~cm}$ at the time the trees were felled. These plantations were then between 40 and 69 years old. General and dendrometric stand characteristics are presented in Table 1. 
Table 1. General characteristics of the 11 sampled Douglas fir plantations. $\mathrm{C}_{\text {mean }}$ : mean circumference of the Douglas firs; $\mathrm{N}_{\text {ha }}$ : number of trees per hectare at the time of tree cutting; $\mathrm{MACI}$ : mean annual circumference increment; $\mathrm{H}_{\mathrm{dom}}$ : dominant height.

\begin{tabular}{|c|c|c|c|c|c|c|c|c|c|}
\hline Stand & Forest District & $\mathbf{N}^{\circ}$ of Rings on Stump & Initial Spacing (m) & Initial Composition & $\mathrm{C}_{\text {mean }}(\mathrm{cm})$ & $\mathbf{N}_{\text {ha }}$ & Basal Area $\left(\mathrm{m}^{2} / \mathrm{ha}\right)$ & MACI (cm/year) & $\mathrm{H}_{\mathrm{dom}}(\mathrm{m})$ \\
\hline SPA & Spa & 69 & $1.5 \times 1.5$ & Pure & 163 & 174 & unknown & 2.3 & 36.3 \\
\hline BEAU & Beauraing & 59 & unknown & Mixt. with Abies sp. & 160 & 175 & 36 & 2.7 & 38.3 \\
\hline VIEL & Vielsalm & 57 & unknown & Pure & 139 & 188 & 30 & 2.8 & 35.9 \\
\hline LIB & Libin & 53 & $1.5 \times 1.5$ & Pure & 155 & 175 & 35 & 3.0 & 37.0 \\
\hline FLA & Florenville & 53 & unknown & Mixt. with Larix sp. & 155 & 225 & 45 & 3.0 & 36.0 \\
\hline BER & Bertrix & 53 & $2.0 \times 1.5$ & Pure & 148 & 243 & 42 & 3.0 & 34.8 \\
\hline FLB & Florenville & 49 & $2.0 \times 2.0$ & Pure & 153 & 211 & 40 & 3.3 & 36.0 \\
\hline DEL & Florenville & 46 & $2.0 \times 2.0$ & Pure & 152 & 158 & 29 & 3.5 & 35.8 \\
\hline REI & Florenville & 45 & $1.8 \times 1.8$ & Mixt. with Picea sp. & 150 & 170 & 31 & 3.6 & 34.3 \\
\hline PHB & Philippeville & 44 & $2.0 \times 2.3$ & Pure & 157 & 142 & 28 & 3.7 & 32.0 \\
\hline PHA & Philippeville & 41 & $2.0 \times 2.3$ & Pure & 143 & 140 & 23 & 4.0 & 33.1 \\
\hline
\end{tabular}


It should be noted that although planting densities varied by a factor of two $( \pm 4400$ in Spa and Libin, vs. \pm 2200 in Philippeville), they were all relatively high in absolute terms-much higher than those characterizing stands studied for a similar objective by, among others, [29]—1000 seedlings/ha, [30]—400 seedlings/ha, or [10]—100 seedlings/ha.

Six trees were collected from within each stand, belonging to circumference classes at $1.5 \mathrm{~m}$ height [120 cm; $129 \mathrm{~cm}],[130 \mathrm{~cm} ; 139 \mathrm{~cm}],[140 \mathrm{~cm} ; 149 \mathrm{~cm}],[150 \mathrm{~cm} ; 159 \mathrm{~cm}],[160 \mathrm{~cm} ; 169 \mathrm{~cm}]$ and $[170 \mathrm{~cm}$; $179 \mathrm{~cm}$ ]. These trees were randomly selected among those supposed to be final crop trees (i.e., they were well shaped, straight grain, displayed well-balanced crown, no apparent curvature of the foot $\log$, etc.). The 66 trees in the sample thus had contrasting individual growth rates: their average ring width $\left(R W_{\text {tree }}\right)$ measured on a disk taken at $2 \mathrm{~m}$ height varied from barely $3 \mathrm{~mm}$ (smallest tree of the oldest stand) to more than $7 \mathrm{~mm}$ (largest tree of the youngest stand). The sample broadly covered the range of $\mathrm{RW}_{\text {tree }}$ encountered within the Walloon Douglas fir stands. However, due to the structure of the sample, it should be noted that $60 \%$ of the trees had a RW between 4 and $5.5 \mathrm{~mm}$ (Figure 1).

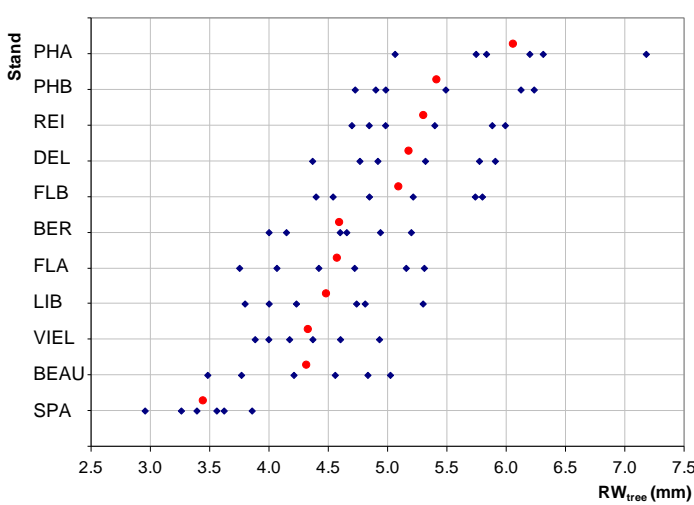

(a)

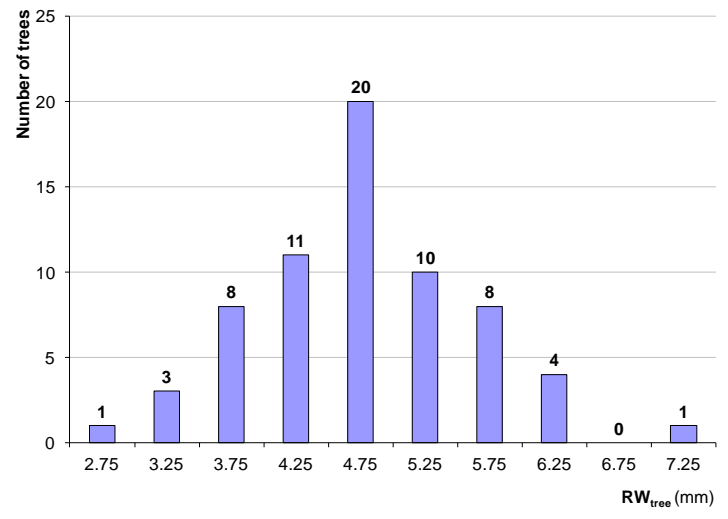

(b)

Figure 1. (a) Mean ring widths of the 66 trees ( $R W_{\text {tree }}$ squares), measured at $2 \mathrm{~m}$ height. For each of the 11 stands, an average $\mathrm{RW}_{\text {tree }}$ was calculated (circles) on the basis of the six individual values; (b) Frequency distribution of $\mathrm{RW}_{\text {tree }}$ in classes of $0.5 \mathrm{~mm}$, from $[2.5 \mathrm{~mm} ; 3.0 \mathrm{~mm}$ ] to $[7.0 \mathrm{~mm} ; 7.5 \mathrm{~mm}$ ].

In order to provide the material for the various tests, the 66 trees were cut according to a common protocol (for more details, see [21]). The boards studied here originated from three log types, as described in Table 2.

Table 2. Characteristics of the analyzed boards.

\begin{tabular}{ccccc}
\hline Cross Section $\left(\mathbf{m m}^{2}\right)$ & Origin & Length $(\mathbf{m})$ & Height in Standing Tree $(\mathbf{m})$ & Number \\
\hline $38 \times 100$ & Log $\mathrm{n}^{\circ} 2$ of 33 trees $([120 ; 129]$, & 2.2 & {$[2.2-4.4]$} & 238 \\
$38 \times 100$ & $[140 ; 149]$ and $[160 ; 169])$ & & & 207 \\
$70 \times 180$ & $\log ^{\circ} 3$ of 33 trees $([120 ; 129]$, & 2.2 & {$[6.0-8.2]$} & 261 \\
\hline
\end{tabular}

${ }^{1}$ The smallest tree of stand PHB broke at $13 \mathrm{~m}$ height when it was cut.

Logs $\mathrm{n}^{\circ} 5$ were entirely cut into $70 \times 180 \mathrm{~mm}^{2}$ boards, producing as many wane-free pieces as possible. On the other hand, the $38 \times 100 \mathrm{~mm}^{2}$ boards taken from logs $\mathrm{n}^{\circ} 2$ and $\mathrm{n}^{\circ} 3$ resulted from the edging of the $110 \mathrm{~mm}$ thick transverse slice centered on the pith and perpendicular to the largest radius of the section (in order to minimize the presence of reaction wood). No $38 \times 100 \mathrm{~mm}^{2}$ boards were taken out of the transverse slice.

These cutting schemes do not necessarily correspond to what would have been done in sawmills. They were underpinned by the carried out visual and mechanical strength grading of the boards 
(remembering that boards of different sections are not affected equally by the presence of knots of a given size, for example). The fact remains that the boards analyzed here allowed an objective evaluation of the impact of tree growth rate on the mechanical properties of the lumber.

With regard to the $44538 \times 100 \mathrm{~mm}^{2}$ boards, the proportion of the section of the log that they represent increases with the distance that separated them from the pith. For some evaluations, it may therefore be suitable to weight the importance of each board in the sample according to its radial position.

\subsection{Methods}

\subsubsection{Measurement of the Boards' Properties}

Before the mechanical trials, a visual strength-grading was carried out on all boards at a moisture content of around $20 \%$, obtained through natural seasoning [21]. Within the framework of this grading, the average ring width observed on each board $\left(\mathrm{RW}_{\text {board }}\right)$ as well as the marginal and total knot area ratios $\left(\mathrm{KAR}_{\mathrm{m}}\right.$ and $\left.\mathrm{KAR}_{\mathrm{t}}\right)$ were determined in accordance with the methodology presented in NBN B $16-520$ [31].

Although it has been mentioned that the transition between core- and outerwood is progressive, it was necessary for the purposes of this study to distinguish sub-samples of boards according to the nature of the wood they were made of, which made it necessary for us to fix a transition age. The compromise adopted in the present study was to consider that the transition between core- and outerwood occurs when the cambial age is 15 years; this is also the compromise adopted by $[16,24,26,32]$. The average cambial age of the $38 \times 100 \mathrm{~mm}^{2}$ boards (Age ${ }_{\text {camb }}$ ) was defined as the age of the ring (counted from the pith) for which roughly $50 \%$ of the wood of the board is older, and $50 \%$ is younger. This characteristic was not determined on the $70 \times 180 \mathrm{~mm}^{2}$ boards. The $38 \times 100 \mathrm{~mm}^{2}$ boards were considered to be exclusively (or almost) made of corewood when their average cambial age was 10 years or less; if Age $_{\text {camb }}$ was 20 years or more, they were considered as mainly composed of outerwood; between these two values, the nature of the boards was considered as mixed.

The physico-mechanical properties considered to determine the potential of wood in structural uses were the density at $12 \%$ humidity $\left(\rho_{12} \%\right)$, the modulus of elasticity in static bending $\left(\mathrm{E}_{\mathrm{m}, \mathrm{g}}, \mathrm{which}\right.$ we will generally call E or stiffness), and the static bending strength $\left(f_{m}\right)$. The characteristic values required in the different mechanical strength classes are defined in EN 338 [33]. These values are the percentile $5 \%$ for $\rho_{12 \%}\left(\rho_{12 \%, \mathrm{k}}\right)$ and $f_{m}\left(f_{m, k}\right)$, and the mean for $\mathrm{E}\left(\mathrm{E}_{\mathrm{mean}}\right)$.

The physico-mechanical properties of the $38 \times 100 \mathrm{~mm}^{2}$ and $70 \times 180 \mathrm{~mm}^{2}$ boards were measured within the facilities of the TERRA Teaching and Research Center (Gembloux Agro-Bio Tech, University of Liège, Liège, Belgium) and of the FCBA Institute of Technology (Bordeaux, France), respectively. Stiffness was determined in accordance with EN 408 [34]. When the boards' moisture content was different from 12\%, $\mathrm{E}_{\mathrm{m}, \mathrm{g}}$ values were adjusted according to the methodology described in EN 384 [35].

After stiffness measurement, the boards were again kept in a conditioned atmosphere and their average moisture content reached the expected $12 \%$. The boards were broken on a test stand and the $f_{m}$ value was determined in accordance with EN 408 [34]. According to EN 384 [35], these values were divided by $(150 / \mathrm{h})^{0.2}$, where $\mathrm{h}$ is the height of the boards in $\mathrm{mm}$.

\subsubsection{Analysis of the Results}

The statistical parameters of position and dispersion of the different board populations considered were calculated using Minitab 17 software (Minitab Inc., State College, PA, USA). Subsequently, the sensitivity of the physical and mechanical properties of boards to tree growth rate is presented graphically and discussed in light of the characteristic values of the mechanical strength classes defined in EN 338 [33]. 


\section{Results and Discussion}

\subsection{General Statistics}

The main descriptive statistics of both lumber populations (depending on their cross section) are presented in Table 3.

Table 3. Physical and mechanical properties measured on the $44538 \times 100 \mathrm{~mm}^{2}$ and $26170 \times 180 \mathrm{~mm}^{2}$ boards studied. The averages for the lowest cross section $\left(38 \times 100 \mathrm{~mm}^{2}\right)$ were calculated on the basis of both the raw values (i.e., not weighted according to the radial position of the boards) and the weighted values; the values for the largest cross section $\left(70 \times 180 \mathrm{~mm}^{2}\right)$ did not require weighting.

\begin{tabular}{ccccccccc}
\hline $\begin{array}{c}\text { Cross Section } \\
\left(\mathbf{m m}^{2}\right)\end{array}$ & Property & Mean & $\begin{array}{c}\text { Weighted } \\
\text { Mean }\end{array}$ & $\begin{array}{c}\text { Standard } \\
\text { Deviation }\end{array}$ & Min. & Max. & $\begin{array}{c}\text { 1st } \\
\text { Quartile }\end{array}$ & $\begin{array}{c}\text { 3rd } \\
\text { Quartile }\end{array}$ \\
\hline \multirow{2}{*}{$38 \times 100$} & $\mathrm{E}(\mathrm{MPa})$ & 11,412 & 11,892 & 2547 & 5870 & 18,695 & 9533 & 13,256 \\
& $f_{m}(\mathrm{MPa})$ & 41.3 & 44.1 & 15.5 & 11.1 & 77.9 & 29.1 & 53.2 \\
& $\begin{array}{c}\rho_{12 \%} \\
\left(\mathrm{~kg} / \mathrm{m}^{3}\right)\end{array}$ & 497 & 505 & 46 & 401 & 631 & 463 & 531 \\
\hline \multirow{2}{*}{$70 \times 180$} & $\mathrm{E}(\mathrm{MPa})$ & 13,047 & - & 2359 & 7353 & 18,517 & 11,247 & 14,690 \\
& $f_{m}(\mathrm{MPa})$ & 36.1 & - & 10.6 & 10.6 & 64.9 & 28.2 & 42.4 \\
& $\begin{array}{l}\rho_{12 \%} \\
\left(\mathrm{~kg} / \mathrm{m}^{3}\right)\end{array}$ & 449 & - & 32 & 359 & 527 & 427 & 471 \\
\hline
\end{tabular}

Regardless of cross-sectional area, the mean values of E determined on Walloon boards were similar to the values reported in [36] for American lumber (these values varied between 10 and $13 \mathrm{GPa}$ ) as well as with the values measured on German Douglas fir lumber [29] (stiffness values of 15,000 MPa are reported in [37], but this author studied much older trees (around 100 years old)). Although [17] do not provide a global average value for their sample of French boards, the $\mathrm{E}$ and $f_{m}$ values they present seem-by comparing the means by $\mathrm{RW}_{\text {board }}$ class—slightly higher than those we observed. In contrast, [38] report slightly lower values. Finally, the E values measured by [15] on British Douglas fir (i.e., slightly over $9 \mathrm{GPa}$ ) are significantly lower than the values measured on other European resources, while the average $f_{m}$ value $\left(34 \mathrm{MPa}\right.$ ) is comparable to that measured on Walloon $70 \times 180 \mathrm{~mm}^{2}$ boards.

At the level of height at which the central area of the $70 \times 180 \mathrm{~mm}^{2}$ boards was located (i.e., approximately $13 \mathrm{~m}$ ), it was estimated that there were on average 7-11 fewer growth rings of outerwood compared to the level at which the central area of the $38 \times 100 \mathrm{~mm}^{2}$ boards from logs three and two was located-respectively cut $6 \mathrm{~m}$ or even $10 \mathrm{~m}$ lower in the trunk. The lower density values presented by the $70 \times 180 \mathrm{~mm}^{2}$ boards are therefore logical since, for a given ring width, corewood density is ca. $10 \%$ lower than that of outerwood $[13,20]$.

If the values presented in Table 3 are compared to those relating to clear wood specimens taken from the basal log of the same trees (see [20]), E and $\rho_{12 \%}$ mean values were relatively similar and hardly affected by the material on which the property was measured. Conversely, $f_{m}$ values measured on structural dimensions boards were less than half those observed on clear specimens (on average $97 \mathrm{MPa}$ ). The higher sensitivity of $f_{m}$ to features (compared to E) relies on the fact that, as reported in previous studies (e.g., [15]) and as it appeared in the present one, stiffness principally depends on density, whilst strength is mainly driven by knottiness.

Finally, it should be noted that the weighted values of E and $f_{m}$ were respectively $4 \%$ and $7 \%$ higher than the raw values, which confirms the slight underestimation of the properties induced by taking into account only the transverse slice in the case of the $38 \times 100 \mathrm{~mm}^{2}$ boards. Concerning $\rho_{12} \%$, the underestimation was less than $2 \%$.

\subsection{Impact of the Wood Type}

The physico-mechanical properties of corewood, outerwood, and mixed $38 \times 100 \mathrm{~mm}^{2}$ boards are presented in Table 4. 
Table 4. Physico-mechanical properties measured on three types of $38 \times 100 \mathrm{~mm}^{2}$ boards: corewood (Age $_{\text {camb }} \leq 10$ years; $\left.n=168\right)$, outerwood (Age camb $\geq 20$ years; $\left.n=184\right)$, or mixed $(n=93)$.

\begin{tabular}{|c|c|c|c|c|c|c|c|c|}
\hline Property & Type of Wood & Mean & $\begin{array}{l}\text { Standard } \\
\text { Deviation }\end{array}$ & Min. & Max. & Percentile 5\% & 1st Quartile & 3rd Quartile \\
\hline \multirow{3}{*}{$\begin{array}{c}\rho_{12 \%} \\
\left(\mathrm{~kg} / \mathrm{m}^{3}\right)\end{array}$} & Corewood & 466 & 34 & 401 & 597 & 417 & 442 & 488 \\
\hline & Mixed & 492 & 38 & 404 & 565 & 429 & 469 & 514 \\
\hline & Outerwood & 528 & 39 & 402 & 631 & 462 & 504 & 556 \\
\hline \multirow{3}{*}{$\mathrm{E}(\mathrm{MPa})$} & Corewood & 9410 & 1758 & 5870 & 16,102 & 6653 & 8067 & 10,699 \\
\hline & Mixed & 11,146 & 1771 & 6983 & 14,441 & 7887 & 9992 & 12415 \\
\hline & Outerwood & 13,375 & 1938 & 8422 & 18,695 & 10,109 & 12,030 & 14,691 \\
\hline \multirow{3}{*}{$f_{m}(\mathrm{MPa})$} & Corewood & 30.7 & 9.9 & 11.1 & 58.3 & 16.0 & 24.5 & 37.3 \\
\hline & Mixed & 38.6 & 12.5 & 12.7 & 67.9 & 16.7 & 29.9 & 47.1 \\
\hline & Outerwood & 52.4 & 13.5 & 16.2 & 77.9 & 29.7 & 42.9 & 63.8 \\
\hline
\end{tabular}

Compared to the values observed on boards cut from outerwood, the mean E values observed on mixed and corewood boards were $17 \%$ and $30 \%$ lower, respectively. Regarding $f_{m}$, these decreases reached $26 \%$ and $41 \%$, while they were only $7 \%$ and $12 \%$ for density. Logically, a one-way ANOVA indicated a very highly significant impact of the type of wood on the boards' physico-mechanical properties ( $p=0.000$ for $\rho_{12} \%$, E and $f_{m}$ ), confirming the bibliographical information and the relevance of taking into account, where possible, the proportion of corewood and outerwood. Moreover, whether considering $\mathrm{E}$ or $f_{m}$, it appears that more than $75 \%$ of the boards taken from outerwood (those of the $2 \mathrm{nd}$, 3rd, and 4th quartiles) had more advantageous properties than those offered by $75 \%$ of those taken from corewood (i.e., the first three quartiles). It should also be noted that a $1 \%$ increase of $f_{m, k}$ would allow the 184 boards taken from outerwood to be assigned to class C30; this once again demonstrates the excellent mechanical properties of the outerwood of this species.

In this context, corewood proportion should be minimized by maintaining relatively high stocking in the initial phase of stand growth. This underlies the interest of natural regeneration, which seems relatively easy to achieve [39,40]. In addition to improving the intrinsic properties of clear wood, this strategy would also generate, through the beneficial effect of competition observed on the branchiness of the trees studied in this research [21] and in many others (e.g., [10,41,42]), lumber with lower knottiness. In this perspective, however, it would be important to ensure that the maturation dynamics (i.e., the age at which wood acquires its mature characteristics) of relatively dense natural seedlings are similar to those observed in plantations where the individuals are exposed to competition much later. It should also be stressed that natural regeneration should obviously only be considered when the genotype of the stand to be regenerated offers the necessary guarantees in terms of the quality of the resource.

\subsection{Impact of the Trees' Growth Rate-RWtree}

Figure 2 illustrates the decrease in density and mechanical performances of the boards due to the increase in growth rate of the trees from which they originated. These decreases were compared with the normative requirements defined in standard EN 338 [33]. 


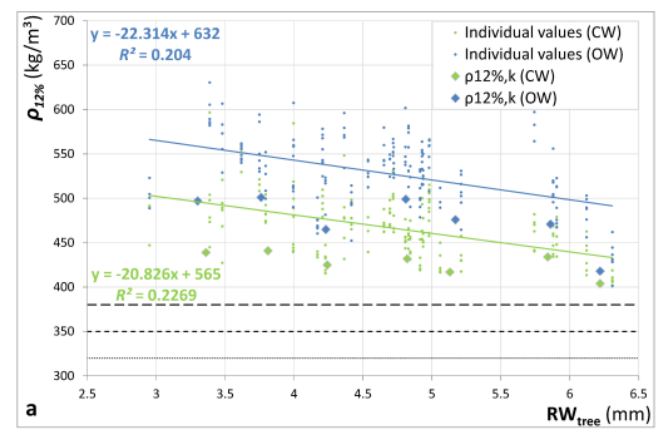

(a)

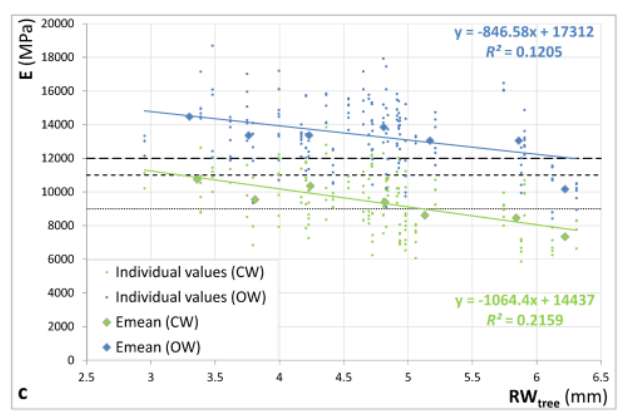

(c)

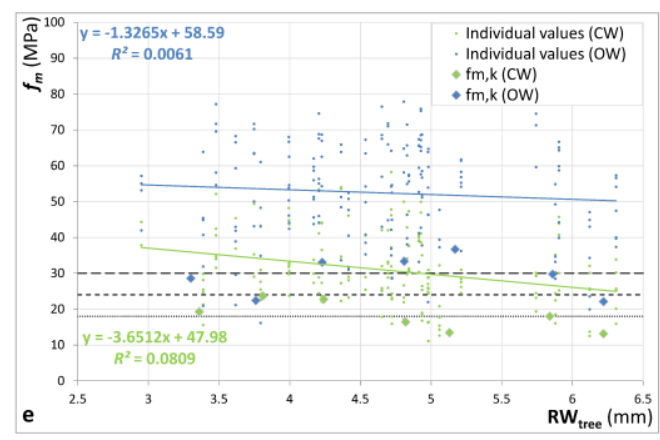

(e)

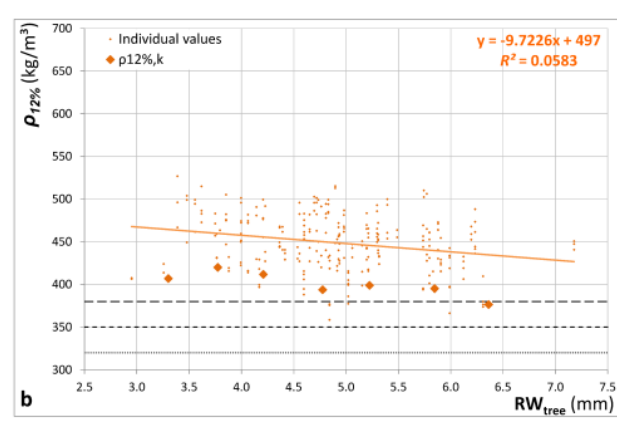

(b)

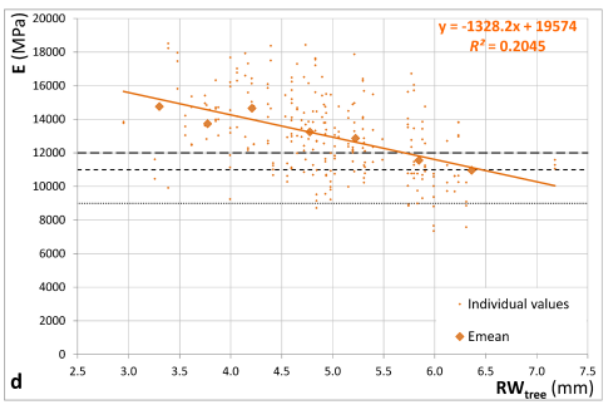

(d)

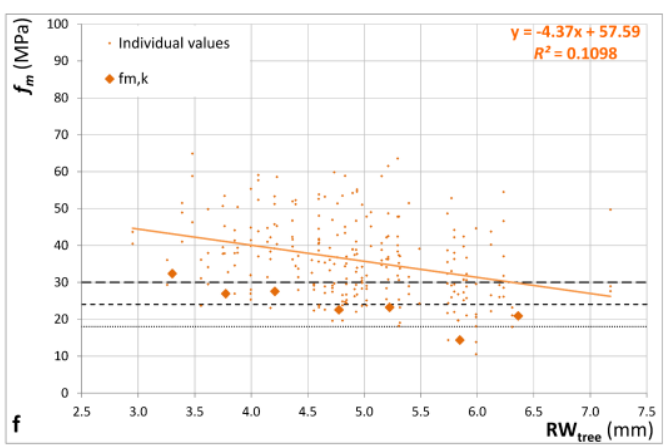

(f)

Figure 2. Density ( $\rho$ : a and b), modulus of elasticity (E: $c$ and $d)$, and static bending strength $\left(f_{m}\right.$ : e and f) at $12 \%$ moisture content of the $44538 \times 100 \mathrm{~mm}^{2}$ (left) and $26170 \times 180 \mathrm{~mm}^{2}$ (right) boards, depending on the growth rate of the trees $\left(\mathrm{RW}_{\text {tree }}\right)$ from which the boards originated. The seven $\mathrm{RW}_{\text {tree }}$ classes (namely: <3.5 mm; [3.5-4 mm]; [4-4.5 mm]; [4.5-5 mm]; [5-5.5 mm]; [5.5-6 mm] and $\geq 6 \mathrm{~mm}$ ) were defined so that each of them contained at least 10 boards. For each property, the dotted lines represent the characteristic values required to comply with (from bottom to the top) strength classes C18, C24 and C30. CW: corewood; OW: outerwood.

As a preamble to the in-depth examination of each graph, the following observations can already be made:

- $\quad$ individual values of $E$ and $f_{m}$ within each class of $\mathrm{RW}_{\text {tree }}$ exhibited a large dispersion;

- the coefficients of determination $\left(r^{2}\right)$ between the studied properties and the radial growth rate of the trees were relatively low, being at best around $20 \%$. Considering the same properties 
measured on clear specimens taken from the same 66 trees, $r^{2}$ values mentioned by [20] were around $10 \%$ in outerwood and from $28 \%$ to $41 \%$ in corewood;

- density is never a limiting parameter for the use of Douglas fir in structural applications: all the marginal characteristic values (i.e., percentile $5 \%$ per $\mathrm{RW}_{\text {tree }}$ class) observed-except that of the $70 \times 180 \mathrm{~mm}^{2}$ boards from trees whose $\mathrm{RW}_{\text {tree }} \geq 6 \mathrm{~mm}$-allowed access to strength class C 30 . This acknowledgement is not surprising given the relatively high density of Douglas fir (compared to spruce in particular), the fact this property is predominantly under genetic control $[43,44]$ and only slightly sensitive to growth rate $[20,25]$, and finally because identical density characteristic values define the strength classes of Norway spruce and Douglas fir.

\subsubsection{Observations on $38 \times 100 \mathrm{~mm}^{2}$ Boards}

For the seven batches defined according to $\mathrm{RW}_{\text {tree }}$ and cut from outerwood, only the batch from trees with a RW exceeding $6 \mathrm{~mm}$ had an average E value incompatible with C30 grading. As far as $f_{m}$ is concerned, the results can be considered identical after a critical examination of the data. Indeed, the surprisingly low $f_{m, k}$ values of the two lowest $\mathrm{RW}_{\text {tree }}$ classes were each due to a single board (for which $f_{m}$ was 20.9 and $16.2 \mathrm{MPa}$, in ascending order of $\mathrm{RW}_{\text {tree}}$ ). These boards were characterized by an average cambial age of 26 and 23 years (which therefore does not formally exclude the presence of corewood) and by very high KAR values, which would even induce the exclusion of one of them according to NBN B 16-520 [31] visual grading. Consequently, in the absence of these two boards, $f_{m, k}$ would increase by more than $30 \%$ in the first two classes of $\mathrm{RW}_{\text {tree }}$ (mean $f_{m}$ values increased by only $3 \%$ and $4 \%$ if these boards were removed from the sub-sample. This illustrates the very high sensitivity of the 5th percentile to extreme values, especially on small sub-samples such as those considered here), reaching values higher than $30 \mathrm{MPa}$. Moreover, it should also be noted that if the mechanical properties of the batch of "outerboards" from trees whose $\mathrm{RW}_{\text {tree }}$ exceeds $6 \mathrm{~mm}$ are clearly lower than those of the other batches, the former nevertheless meets the requirements of C18 strength class.

Considering the batches of boards taken from corewood, the characteristic values of the mechanical properties ( $\mathrm{E}_{\text {mean }}$ and $f_{m, k}$ ) best met the requirements of strength class $\mathrm{C} 18$; these requirements were no longer met beyond an average growth rate of 4.5 to $5 \mathrm{~mm}$ (depending on whether $f_{m}$ or E was considered).

The results observed on the $38 \times 100 \mathrm{~mm}^{2}$ boards corroborate the observations made on clear specimens taken from the same trees [20]: both approaches demonstrated the different sensitivity of core- and outerwood mechanical properties to growth rate. In more practical terms, the results show that enhancing growth mainly affects corewood mechanical properties, with little impact on those of outerwood.

\subsubsection{Observations on $70 \times 180 \mathrm{~mm}^{2}$ Boards}

From a qualitative point of view, the trends observed on $70 \times 180 \mathrm{~mm}^{2}$ boards were identical to those made on the boards with smaller cross-sectional area: the three properties studied here decreased as $\mathrm{RW}_{\text {tree }}$ increased.

The lower average density of the $70 \times 180 \mathrm{~mm}^{2}$ boards (compared to that of the $38 \times 100 \mathrm{~mm}^{2}$ boards) due to an increased proportion of corewood was already discussed in Table 4. If logically it also appears by considering the characteristic values per $\mathrm{RW}_{\text {tree }}$ class, this decrease in density does not compromise the possibilities of using the wood in construction.

$\mathrm{Up}$ to $\mathrm{RW}$ tree of $6 \mathrm{~mm}, \mathrm{E}_{\text {mean }}$ values complied with the requirements of the $\mathrm{C} 24$ strength class (and even of $\mathrm{C} 30$ if $\mathrm{RW}_{\text {tree }}<5.5 \mathrm{~mm}$ ). Concerning the batch from the highest $\mathrm{RW}_{\text {tree }}$ class $(>6 \mathrm{~mm})$, excluding the only board with a value of $\mathrm{E}<8000 \mathrm{MPa}$ (which according to a visual grading would have been excluded from structural uses because of its knottiness) would be sufficient to raise $E_{\text {mean }}$ to over $11,000 \mathrm{MPa}$ - a value which would allow the batch to be assigned to the C24 class.

Finally, if we examine $f_{m, k}$, six of the seven batches defined on the basis of $\mathrm{RW}_{\text {tree }}$ were suitable for structural uses. The batch from class $[5.5 ; 6 \mathrm{~mm}]$ was heavily penalized by three boards exhibiting 
$f_{m}$ of less than $15 \mathrm{MPa}$. Because of their knottiness, two of these boards would have been rejected as part of a visual grading, which would have led to an increase in $f_{m, k}$ above $18 \mathrm{MPa}$.

\subsubsection{Structural Use Ability}

Table 5 concludes the analysis of these data by allowing an overview of the structural use potential of the boards as a function of tree growth rate. It is based on the observations made in Figure 2-namely that, for the 21 combinations studied (three types of boards $\times$ seven $\mathrm{RW}_{\text {tree }}$ classes), $f_{m, k}$ was always more limiting than $\mathrm{E}_{\text {mean }}$ (remembering that, in practice, density never impedes accessing the highest mechanical class). It should however be noted that $\mathrm{E}$ is often more important than $f_{m}$ in the dimensioning of structures: The cross sections imposed by the project managers are indeed calculated above all to maintain the deformations of the structure below a given level, which is obviously much lower than that required to break the components of this structure. Table 5 is only valid for the samples studied here and was drawn up on the basis of the "reasoned values" (i.e., taking into account the critical interpretation of the trends observed as carried out in Sections 3.3.1 and 3.3.2).

Table 5. Structural use ability of the studied board batches according to the characteristic values of $\mathrm{E}$ and $f_{m}$ and of the growth rate of the trees from which the boards originate.

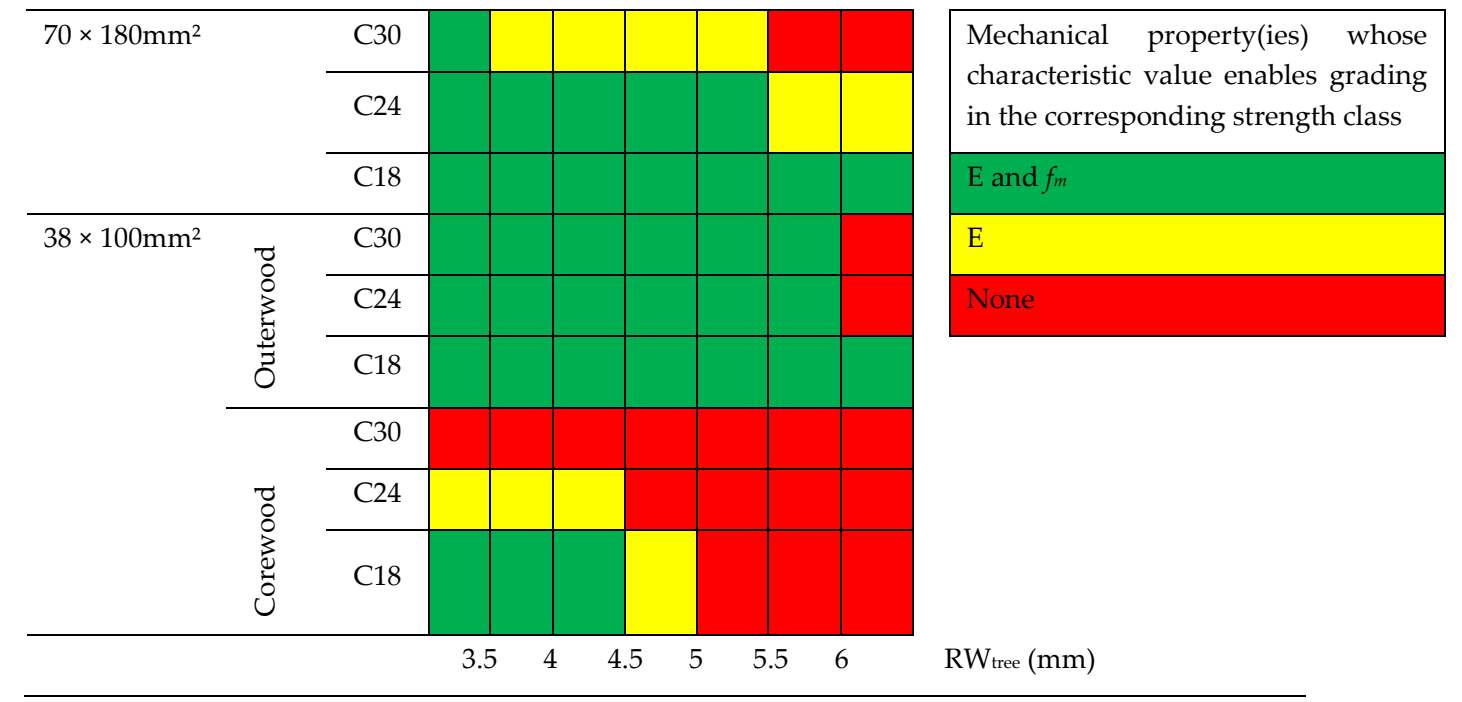

Table 5 shows that the batches of $38 \times 100 \mathrm{~mm}^{2}$ boards taken from corewood had generally poor properties which, with the exception of those from trees with $\mathrm{RW}_{\text {tree }}<4.5 \mathrm{~mm}$ (with the exception of the SPA stand, where all individuals displayed a $\mathrm{RW}_{\text {tree }}<4.5 \mathrm{~mm}$, the latter value was exceeded for all dominant trees in the other 10 stands), require individual grading of these boards. In contrast, it appears that, up to a $5.5 \mathrm{~mm} \mathrm{RW}$ tree, batches of $38 \times 100 \mathrm{~mm}^{2}$ boards taken from outerwood and batches of $70 \times 180 \mathrm{~mm}^{2}$ boards could be assigned to strength class C24 or even C30.

\section{Conclusions}

This research aimed to identify as precisely as possible the influence of growth rate on the physico-mechanical properties of Douglas fir boards-in particular on their suitability for structural use with respect to normative characteristic values.

Remembering that planting densities in the studied stands were relatively high compared to those observed in neighboring countries, it is reassuring to note that in the range of growth rates and cross sections tested, lumber from outerwood offered very good properties, even in trees and stands with the highest growth rates. Conversely, lumber taken from corewood appeared to be rather sensitive to growth rate, and its suitability for structural uses decreased significantly as ring width increased. 
Hence, by minimizing both the proportion of corewood and sapwood, increasing rotation length only has advantages from a purely technological point of view. The extent to which these must be subordinated to increased health and climate risks, to the negative impact on the profitability of longer investments, or to the reduction in the adaptation of logs to current industrial tools must now be determined.

Author Contributions: B.J. and J.H. conceived and supervised this research; J.-M.H. and C.P. analyzed the data and wrote the paper.

Acknowledgments: The authors wish to thank A. Bauvin, S. Sliwinski, C. Verheyen and Messrs F. Raskin and A. Vandersteen (SPW), as well as Messrs L. Hadiy and P. Thibaut (ULiège, GxABT) for their technical assistance. The staff of the FCBA Bordeaux, and in particular Didier Reuling, is also thanked for the mechanical tests carried out on the $70 \times 180 \mathrm{~mm}^{2}$ boards. Y. Brostaux and C. Lesire (ULiège, GxABT) kindly participated in the statistical analyses, only part of which is presented in this article. All the forest managers and owners who made this study possible are also thanked. Finally, we are indebted to two anonymous reviewers for their kind contribution in improving the initial version of the manuscript. This research was granted by the Public Service of Wallonia. The latter is the owner of the data, which therefore are not open to public access.

Conflicts of Interest: The authors declare no conflict of interest. The founding institution (Public Service of Wallonia) had no role in the design of the study; in the collection, analyses, or interpretation of data; in the writing of the manuscript, and in the decision to publish the results.

\section{References}

1. Alderweireld, M.; Burnay, F.; Pitchugin, M.; Lecomte, H. Inventaire Forestier Wallon. Résultats 1994-2012; Service Public de Wallonie, DGO3, DNF; Direction des Ressources Forestières: Jambes, Belgique, 2015; p. 236.

2. Biévelet, C.; Henin, J.-M.; Jourez, B.; Hébert, J.; Lecomte, H. Le Douglas en Région Wallonne-Etat des lieux et tendances. For. Wallonne 2007, 90, 27-39.

3. Henin, J.-M.; Pollet, C.; Schmitt, U.; Blohm, J.-H.; Koch, G.; Melcher, E.; Welling, J.; Brüchert, F.; Kohnle, U.; Sauter, U.H. Technological properties of Douglas-fir wood. In Douglas-Fir-An Option for Europe; Spiecker, H., Schuler, J., Eds.; European Forest Institute: Joensuu, Finland, 2018, in press.

4. Pollet, C.; Henin, J.-M.; Hébert, J.; Jourez, B. Impact de la vitesse de croissance sur les propriétés technologiques du bois de Douglas. For. Nat. 2018, 146, 60-72.

5. Perin, J.; Claessens, H.; Hébert, J. Nouvelles courbes de productivité pour le Douglas en Région wallonne. For. Wallonne 2009, 98, 22-28.

6. Perin, J.; De Thier, O.; Claessens, H.; Lejeune, P.; Hébert, J. Nouvelles courbes de productivité harmonisées pour le Douglas, l'Epicéa et les Mélèzes en Wallonie. For. Wallonne 2014, 129, $26-41$.

7. Perin, J.; Hébert, J.; Lejeune, P.; Claessens, H. De nouvelles normes sylvicoles pour les futaies pures équiennes d'épicéa et de douglas en appui à la gestion de la forêt publique en Wallonie. For. Nat. 2016, 139, 57-67.

8. Claessens, H.; Thibaut, A.; Rondeux, J. Le Douglas en Belgique; Centre de Recherche et de Promotion Forestières: Gembloux, Belgium, 1996; p. 142.

9. Riou-Nivert, P. Les densités de plantation des résineux. Facteurs de choix et implications. For. Entrep. 2009, $188,13-17$.

10. Hein, S.; Weiskittel, A.R.; Kohnle, U. Effect of wide spacing on tree growth, branch and sapwood properties of young Douglas-fir [Pseudotsuga menziesii (Mirb.) Franco] in south-western Germany. Eur. J. For. Res. 2008, 127, 481-493. [CrossRef]

11. Paulus, J.; Riou-Nivert, P. Bilan national sur le dépressage du douglas. For. Entrep. 2009, 188, 18-22.

12. Rais, A.M. Growth and Wood Quality of Douglas Fir. Ph.D. Thesis, Technical University of München, München, Germany, 2014; p. 139.

13. Blohm, J.-H. Holzqualität und Eigenschaften des Juvenilen und Adulten Holzes der Douglasie (Pseudotsuga menziesii (Mirb.) Franco) aus Süddeutschen Anbaugebieten. Ph.D. Thesis, University of Hamburg, Hamburg, Germany, 2015; p. 174.

14. Bawcombe, J.M. A Study of Douglas-Fir Anatomical and Mechanical Properties and Their Interactions. Ph.D. Thesis, University of Bath, Bath, UK, 2012; p. 360. Available online: http:/ / opus.bath.ac.uk/32245/ (accessed on June 7th 2018). 
15. Drewett, T.A. The Growth and Quality of UK-Grown Douglas-Fir. Ph.D. Thesis, Edinburgh Napier University, Edinburgh, UK, 2015; p. 224. Available online: http:/ / www.napier.ac.uk/research-and-innovation/researchsearch/outputs/the-growth-and-quality-of-uk-grown-douglasfir (accessed on June 7th 2018).

16. Melin, N.; Riou-Nivert, P. La qualité du douglas dépend-elle de la sylviculture? For. Entrep. 1985, 32, 18-24.

17. Nepveu, G.; Blachon, J.L. Largeur de cerne et aptitude à l'usage en structure de quelques conifères: Douglas, Pin sylvestre, Pin maritime, Epicéa de Sitka, Epicéa commun, Sapin pectiné. Rev. For. Fr. 1989, XLI, 497-506. [CrossRef]

18. Riou-Nivert, P. Douglas, qualité du bois, élagage et sylviculture. Rev. For. Fr. 1989, XLI, 387-410. [CrossRef]

19. Pollet, C.; Henin, J.-M.; Hébert, J.; Jourez, B. Effect of growth rate on the natural durability of Douglas-fir in Western Europe. Can. J. For. Res. 2013, 43, 891-896. [CrossRef]

20. Pollet, C.; Henin, J.-M.; Hébert, J.; Jourez, B. Effect of growth rate on the physical and mechanical properties of Douglas-fir in Western Europe. Can. J. For. Res. 2017, 47, 1056-1065. [CrossRef]

21. Henin, J.-M.; Pollet, C.; Hébert, J.; Jourez, B. Valorisation du Douglas en bois de structure et bardages: Impact de la vitesse de croissance des arbres. For. Wallonne 2009, 98, 29-38.

22. Henin, J.-M.; Pollet, C.; Jourez, B.; Hébert, J. Assessment of the Belgian visual strength grading Standard NBN B 16-520: Douglas-fir lumber as a case study. In Proceedings of the IUFRO Conference of Units 5.01.04 and 3.04.02 “Wood QC: A Wood Quality and Supply Chain Modelling Conference", Québec, QC, Canada, 12-17 June 2016.

23. Burdon, R.D.; Kibblewhite, R.P.; Walker, J.C.F.; Megraw, R.A.; Evans, R.; Cown, D.J. Juvenile versus mature wood: A new concept, orthogonal to corewood versus outerwood, with special reference to Pinus radiata and P. taeda. For. Sci. 2004, 50, 399-415.

24. Zobel, B.J.; Sprague, J.R. Juvenile Wood in Forest Trees; Springer: Berlin, Germany, 1998; p. 300.

25. Megraw, R.A. Douglas-fir wood properties. In Douglas-Fir: Stand Management for the Future; Oliver, C.D.O., Hanley, D.P., Johnson, J.A., Eds.; Institute of Forest Resources, University of Washington: Seattle, WA, USA, 1986; pp. 81-96.

26. Knowles, L.; Hansen, L.; Downes, G.; Kimberley, M.; Gaunt, D.; Lee, J.; Roper, J. Modelling within-tree and between-tree variation in Douglas-fir wood and lumber properties. In Proceedings of the IUFRO Division 5 Conference, Rotorua, New Zealand, 11-15 March 2003.

27. Abdel-Gadir, A.Y.; Krahmer, R.L. Genetic variation in the age of demarcation between juvenile and mature wood in Douglas-fir. Wood Fiber Sci. 1993, 25, 384-394.

28. Blohm, J.-H.; Evans, R.; Koch, G.; Schmitt, U. Identification and characterisation of Douglas-fir (Pseudotsuga menziesii (Mirb.) Franco) juvenile and adult wood grown in Southern Germany. Drewno 2016, 59, 41-47.

29. Rais, A.; Poschenrieder, W.; Pretzsch, H.; van de Kuilen, J.-W.G. Influence of initial plant density on sawn timber properties for Douglas-fir (Pseudotsuga menziesii (Mirb.) Franco). Ann. For. Sci. 2014, 71, 617-626. [CrossRef]

30. Polge, H. Influence des espacements de plantation sur la qualité du bois de Douglas. For. Entrep. 1984, 17, 16-20.

31. NBN B 16-520, Visual Strength Grading of Structural Timber with Rectangular Cross Section; Bureau de Normalisation: Brussels, Belgium, 2009.

32. Lausberg, M.J.F.; Cown, D.J.; McConchie, D.L.; Skipwith, J.H. Variation in some wood properties of Pseudotsuga menziesii provenances grown in New Zealand. N. Z. J. For. Sci. 1996, 25, 133-146.

33. CEN, 2016. EN 338-Structural Timber—Strength Classes; BSI: Brussels, Belgium, 2016.

34. CEN, 2012. EN 408+A1-Timber Structures-Structural Timber and Glued Laminated Timber-Determination of Some Physical and Mechanical Properties; BSI: Brussels, Belgium, 2012.

35. CEN, 2016. EN 384-Structural Timber-Determination of Characteristic Values of Mechanical Properties and Density; BSI: Brussels, Belgium, 2016.

36. Jayawickrama, K.J.S.; Ye, T.Z.; Gupta, R.; Cherry, M.L. Including Wood Stiffness in Tree Improvement of Coastal Douglas-Fir in the US Pacific Northwest: A Literature Review and Synthesis; Research Contribution 50; Forest Research Laboratory, Oregon State University: Corvallis, OR, USA, 2009; p. 95.

37. Sauter, U.H. Technologische Holzeigenschaften der Douglasie (Pseudotsuga menziesii (Mirb.) Franco) als Ausprägung unterschiedlicher Wachstumsbedingungen. Ph.D. Thesis, Universität Freiburg, Freiburg im Breisgau, Germany, 1992; p. 221. 
38. Viguier, J.; Bourreau, D.; Bocquet, J.-F.; Pot, G.; Bléron, L.; Lanvin, J.-D. Modelling mechanical properties of spruce and Douglas fir timber by means of X-ray and grain angle measurements for strength grading purpose. Eur. J. Wood Wood Prod. 2017, 75, 527-541. [CrossRef]

39. Petit, S.; Claessens, H. La régénération naturelle des douglasaies a le vent en poupe. Le point sur les itinéraires techniques existants. For. Wallonne 2013, 126, 40-52.

40. Petit, S.; Claessens, H.; Ligot, G. Quel type de peuplement pour un renouvellement naturel du douglas. For. Wallonne 2013, 122, 3-12.

41. Hébert, J.; Bailly, F.; Brunin, E.; Herman, M.; Jourez, B. Valorisation des petits bois rouges en Région wallonne. For. Wallonne 2005, 75, 19-31.

42. Briggs, D.; Ingaramo, L.; Turnblom, E. Number and diameter of breast-height region branches in a Douglas-fir spacing trial and linkage to log quality. For. Prod. J. 2007, 57, 28-34.

43. Vargas-Hernandez, J.; Adams, W.T. Genetic variation of wood density components in young coastal Douglas fir: implications for tree breeding. Can. J. For. Res. 1991, 21, 1801-1807. [CrossRef]

44. Rozenberg, P.; Franc, A.; Bastien, C.; Cahalan, C. Improving models of wood density by including genetic effects: A case study in Douglas-fir. Ann. For. Sci. 2001, 58, 385-394. [CrossRef]

(C) 2018 by the authors. Licensee MDPI, Basel, Switzerland. This article is an open access article distributed under the terms and conditions of the Creative Commons Attribution (CC BY) license (http:/ / creativecommons.org/licenses/by/4.0/). 